NBER WORKING PAPER SERIES

\title{
ARE PRUDENTIAL SUPERVISION AND REGULATION PILLARS OF FINANCIAL STABILITY? EVIDENCE FROM THE GREAT DEPRESSION
}

\author{
Kris James Mitchener \\ Working Paper 12074 \\ http://www.nber.org/papers/w12074
NATIONAL BUREAU OF ECONOMIC RESEARCH
1050 Massachusetts Avenue
Cambridge, MA 02138
March 2006

A version of this paper is forthcoming in the Journal of Law and Economics. I am grateful for comments and suggestions provided by Brad DeLong, Barry Eichengreen, Cristian Echeverria, Dwight Jaffee, Joe Mason, Darren Lubotsky, Martha Olney, Mark Rodini, Christina Romer, and Sally Woodhouse as well as seminar participants at the University of Adelaide, the Bank for International Settlements, Bocconi University, Santa Clara University, Trinity University, Wellesley College, the Federal Reserve Banks of Boston and New York, and the Board of Governors of the Federal Reserve System. The views expressed herein are those of the author(s) and do not necessarily reflect the views of the National Bureau of Economic Research.

(C)2006 by Kris James Mitchener. All rights reserved. Short sections of text, not to exceed two paragraphs, may be quoted without explicit permission provided that full credit, including () notice, is given to the source. 
Are Prudential Supervision and Regulation Pillars of Financial Stability? Evidence from the Great Depression

Kris James Mitchener

NBER Working Paper No. 12074

March 2006

JEL No. N2, E44, G21

\begin{abstract}
Drawing on the variation in financial distress across U.S. states during the Great Depression, this article suggests how bank supervision and regulation affected banking stability during the Great Depression. In response to well-organized interest groups and public concern over the bank failures of the 1920s, many U.S. states adopted supervisory and regulatory standards that undermined the stability of state banking systems in the 1930s. Those states that prohibited branch banking, had higher reserve requirements, granted their supervisors longer term lengths, or restricted the ability of supervisors to liquidate banks quickly experienced higher state bank suspension rates from 1929 to 1933.
\end{abstract}

Kris James Mitchener

Department of Economics

Leavey School of Business

Santa Clara University

Santa Clara, CA 95053

and NBER

kmitchener@scu.edu 


\section{INTRODUCTION}

Costly banking crises in both developing and industrial economies over the past several decades have rekindled interest in understanding how supervisory and regulatory structures affect the stability of banking systems. ${ }^{1}$ Led by the Basel Committee, policymakers have responded by providing a blueprint for harmonizing banking supervision throughout the world. ${ }^{2}$ What has been slower to emerge is a consensus on how bank supervision and regulation affect financial stability, and which supervisory practices or quantitative rules, in particular, promote or discourage financial stability. Analysis has been hampered in part by the difficulty of assembling data with sufficient cross-sectional variation to test competing theories. ${ }^{3}$

Prudential regulation was also of interest to policymakers of the 1930 s, when there were significant banking crises both within and across countries. ${ }^{4}$ In the United States, for example, over a third of all commercial banks suspended operations. What is less appreciated is the degree to which banking distress varied across U.S. states (Figure 1), and the extent to which state banking departments had established different prudential regimes. State banking departments and legislatures, acting independently of one another, had instituted their own reserve and capital requirements and branching laws for state-chartered banks. And in contrast to national banks (which had a uniform system of supervision operating through the Office of the Comptroller of Currency), state banking departments differed significantly in terms of the quality of their supervision and their authority to charter and liquidate state-chartered banks.

\footnotetext{
${ }^{1}$ For a discussion of prudential standards, see Folkerts-Landau and Lindgren (1998) and Herring and Litan (1995). For discussion of recent crises, see Caprio and Klingebiel (1996).

2 The Basel Committee's “Core Principles for Effective Banking Supervision” outlines 25 basic standards relating to preconditions for effective supervision, licensing and structure, prudential regulation and requirements, methods of ongoing supervision, information requirements, formal powers of supervisors, and cross-border banking.

${ }^{3}$ Barth, Caprio, and Levine (2001a) have assembled invaluable data on recent regulatory and supervisory practices across 170 countries. However, since much of the data post-date the financial crises of the last two decades, the ability to test and quantify how supervision and regulation affect financial stability is somewhat limited (Barth, Caprio, and Levine, 2001b, p.31). Rossi (1999) has also examined these issues for a small sample of 15 developing countries.

4 Friedman and Schwartz (1963), Bernanke and James (1991), and Grossman (1994). For a discussion of prudential regulation from the 1930s, see Study Commission for Indiana Financial Institutions (1932).
} 
Drawing on this rich cross-sectional and time-series variation of U.S. states, this article examines whether differences in prudential supervision and regulation help account for the regional variation in state bank suspension rates and the shares of total assets and deposits in suspended institutions during the Great Depression. In contrast to previous research that has not addressed the role of bank supervision (Grossman 1994; Wheelock 1995; Wicker 1996), this paper utilizes a new historical data set with information on the authority and quality of state banking departments, as well as data on prudential regulations and branching laws, to test explicitly both pillars of the institutional environment. Since supervision and regulation work together to influence bank behavior and systemic stability (Mishkin 2001), estimating both factors reduces the likelihood of omitted variables bias and provides greater insight into how the overall policy environment affected financial stability.

Examining the variation in financial distress across states rather than countries may also produce better empirical estimates of the effects of bank regulation and supervision on financial stability. First, they may be less susceptible to omitted variables bias since countries likely differ in additional ways (other than supervision and regulation) that influence financial fragility. Second, even if observable differences such as financial development, legal systems, and political systems can be accounted for, differences in financial stability due to unobservable characteristics will also likely be more pronounced for countries than for states. Using state data thus mitigates the problem of unobserved heterogeneity. Third, accounting for the simultaneity between financial instability and economic conditions is a thorny estimation that is made more tractable in the context of the U.S. dual banking system. National bank failure rates can be used to control for shocks affecting all banks within a state since they were uniformly supervised and regulated by the Office of the Comptroller of Currency.

The analysis also places the regulatory environment squarely in the context of politics and history in order to analyze both the causes and consequences of state bank regulation during the Great Depression. In the spirit of recent research emphasizing how bank regulations are produced (for example, Kroszner and Strahan 1999, 2001), competing theories of regulation are 
used to inform the selection of instrumental variables in order to deal with the potential endogeneity of bank regulation.

This article shows that differences in state bank regulations and supervisory structures help explain why the banking crisis of the Depression was worse in some regions of the U.S. As a result of the private motives of interest groups and the public response to previous banking crises, some states adopted stricter reserve requirements and laws forbidding branch banking; this in turn led to higher bank suspension rates for state banks from 1929 to 1933 . Moreover, states that attempted to insulate their bank superintendents from political influence by lengthening the terms of their superintendents or giving them the sole authority to charter banks also increased the incentives for the banking industry to influence these regulatory agencies; this had surprising and counterproductive consequences during the Depression. Finally, giving regulators sufficient powers and resources to carry out their supervisory mandate also increased systemic safety. State bank suspension rates were lower in states where bank supervisors had the authority to liquidate banks without the court system first having to appoint a receiver, and the share of assets and deposits in suspended banks was smaller in states where regulators were given more resources to carry out examinations.

Sections 2 provides a brief overview of the regional nature of the U.S. banking crisis during the Great Depression, discusses the characteristics of state bank supervision and regulation on the eve of the Depression, and relates them to the theoretical literature on banking stability. Sections 3 and 4 estimate and analyze the impact of regulatory and supervisory differences on state bank suspensions from 1929-33. Section 5 then tests for their impact on the share of assets and deposits in suspended banks and provides instrumental variable estimates.

\section{BANK FAILURES AND PRUDENTIAL STRUCTURES FOR STATE BANKS}

In a four-year period, over 9,000 commercial banks suspended operations in the U.S., the majority of which failed. In 1931, nearly 8 percent of all banks failed; by 1933, this figure reached an astounding 20 percent. As Figure 1 shows, there were also large differences in failure 
rates that existed across states, with the Midwest and South exhibiting the highest average failure rates from 1929-33. Bank failures also differed by charter status (Table 1). State banks (regulated by state banking departments) had more total failures than national banks (regulated by the Office of the Comptroller of Currency): 7,429 versus 2,011. This was in part due to their numerical superiority, but from 1929-33, failure rates for state-chartered banks were also on average nearly 4 percentage points higher than national banks (10.2 percent versus 6.8 percent). ${ }^{5}$

A considerable literature exists on the causes of U.S. bank failures during the Depression (Friedman and Schwartz 1963; Temin 1976; White 1984; Wicker 1980, 1996; Calomiris and Mason 2000, 2003); however, few researchers have examined why there was significant variation in bank suspensions across states. ${ }^{6}$ This article focuses on explaining the variation in suspension rates for state-chartered, non-Federal Reserve commercial banks since the variables of ultimate interest, supervision and regulation, differed across states for these financial institutions and since these banks experienced very high suspension rates. ${ }^{7}$ This section relates differences in state bank regulation and supervision to the theoretical and empirical literature on prudential structures and financial stability to show how these differences may have influenced financial stability during the Depression.

\section{A. Branch banking laws, reserve requirements, and capital requirements}

The National Banking Acts of the 1860s effectively created a dual banking system whereby financial institutions could obtain a state bank charter from a state's supervisory office

\footnotetext{
${ }^{5}$ Differences by charter status are somewhat overstated, since the data for state banks are suspensions and those for national banks are receiverships (a subset of suspensions). Nevertheless, the vast majority of state bank suspensions are banks that eventually entered receivership, especially for the period 1929-32. Even if we exclude 1933, the year with the most suspensions, the difference between the rates is still large. The suspension rate is $7.8 \%$ for state banks and the receivership rate is $3.8 \%$ for national banks. Averages for individual years during the Great Depression also exhibit this gap between rates for state and national banks. Throughout the article, we refer to bank failures as the number of banks suspended, according to the Federal Reserve (1937) definition. For further discussion see footnotes 17 and 18.

${ }^{6}$ Gambs (1977) and Wheelock (1995) examine the Depression from a regional perspective.

${ }^{7}$ From 1929 to 1933, nonmember banks, the sample studied here, accounted for between 65 percent and 83 percent of all bank failures across states. Since Fed members had direct access to the discount window but were also subject to different regulations than non-member state banks (e.g., capital and reserve requirements), we exclude them from the analysis.
} 
or a national bank charter from the Office of the Comptroller of the Currency (OCC). In theory, state banking departments could have adopted the supervisory and regulatory system of the national banking system so that prudential systems would have been homogeneous in 1929. In practice, state legislative decisions were influenced by well-organized interest groups (such as unit banks, small manufacturing firms, and insurance companies), public response to the bank failures and failed state deposit insurance systems of the 1920s, and to a lesser extent, competition with federal regulators so that branching laws, capital requirements, and reserve requirements differed significantly by 1929. (See the Appendix for further discussion.)

Laws permitting branch banking are often cited as reducing financial instability by enabling banks to diversify their portfolios over a wider geographical area or customer base, or by introducing competition into a previously geographically-segmented market and removing inefficient banks from the system (Sprague 1903; Benston 1986; Friedman and Schwartz 1963; Grossman 1994; Calomiris 2000; Laderman, Schmidt, and Zimmerman 1991; Jayaratne and Strahan 1997, 1998; Stiroh and Strahan 2003). Although interstate or nationwide branch banking was prohibited, intrastate branch banking began to flourish in the 1920s despite the opposition of unit banks. $^{8}$ As of 1929, 25 states and the District of Columbia permitted some form of branching for state chartered banks (at the state, county, or city level) or did not explicitly prohibit it by law (Table 2); national banks, on the other hand, were constrained by OCC regulations, and were permitted to open branches only in home-office cities in states with legalized branching. ${ }^{9}$

Some researchers have also suggested that capital requirements affect the probability of failure of financial institutions (Hunter, Verbrugge, and Whidbee 1996). The larger the contributions of the shareholders or owners to capital, the greater can be the shrinkage of assets without impairing depositors' claims (Dewatripont and Tirole 1994). Capital requirements can

\footnotetext{
${ }^{8}$ Some state legislators and regulators were motivated to allow branching out of public concern over depositor safety (Mitchener 2001) or with the design of providing a competitive advantage to statechartered institutions vis-à-vis national banks (White, 1983).

${ }^{9}$ The McFadden Act of 1927 legislated that national banks and state Fed member banks were permitted to establish local branches in the city of their home office if a state law allowed branching; however, the number of branches was restricted by city size (Tippetts 1929).
} 
also alter bank decisions regarding risk since they could potentially serve to chasten owners (and their managers) from taking on excessively risky loan portfolios, thus reining in moral hazard. ${ }^{10}$ Because bank capital was one of the main forms of depositor protection prior to 1934 and the creation of federal deposit insurance (Benston and Kauffman 1994), differences in charter capital requirements for state banks might also account for some of the geographical variation in banking distress during the Great Depression. In 1929, 21 states had established capital requirements below the national bank requirement of $\$ 25,000$ (the level applied to banks operating in cities of fewer than 3,000 people), and some contemporaries argued that these low capital requirements encouraged the formation of small unit banks, leading to "excess competition," "overbanking," and more failures in the 1920s and 1930s (Dowrie 1930; American Bankers Association 1935).

Finally, without reserve requirements, banks may be prone to hold too few reserves since they are driven to compete for depositors and increase their asset portfolio returns. Such behavior can increase systemic risk, which suggests that a socially superior outcome is possible through regulation (Cothren and Waud 1994). On the other hand, prudential regulations can reduce monitoring incentives and result in lower quality bank portfolios (Besanko and Kanatas 1993; Boot and Greenbaum 1993). Reserve requirements aimed at protecting depositors from bank runs could thus impose a regulatory cost or burden on the level and composition of reserves a bank would voluntarily hold. As of 1929, all state-chartered banks faced reserve requirements on demand deposits, and most had rates higher than the required rate of 7 percent for Fed members or national banks (Table 2).

\section{B. Supervisory quality, independence, and authority}

Since it is difficult for depositors to monitor bank-lending activities and ensure that banks are not taking excessive risks, bank supervision working in conjunction with prudential regulation can theoretically reduce asymmetric information between depositors and banks (such as adverse

\footnotetext{
${ }^{10}$ The theoretical literature is mixed. For example, Kahane (1977), Kim and Santomero (1988), and Blum (1999) argue that capital requirements could increase risk.
} 
selection and moral hazard) and improve financial stability (Mishkin 2001). Governments have often granted supervisory agencies authority to license banks, authorize branches, or liquidate banks; to make qualitative judgments about the integrity and competence of management; and to ensure compliance with quantitative rules or prudential ratios. The stability of state banking systems therefore may have been influenced not only by transparent bank regulations, but also by the authority of supervisors, the impartiality and objectivity of those vested with such powers, and the quality of the supervisory institutions.

Folkerts-Landau and Lindgren (1998) argue that banking supervisors need sufficient political autonomy to resist pressure from banks, their shareholders, and government officials. In the 1920s and 1930s, many state bank commissioners complained that partisan politics undermined their ability to effectively monitor banks. ${ }^{11}$ Because 44 of the 48 state banking superintendents or supervisors were appointed by a governor, some were particularly concerned that their ability to monitor banks or make chartering decisions was compromised by a lack of insulation from the governors who appointed them. ${ }^{12}$ In 1929, many state supervisors were thus advocating terms of appointment that were longer than the election cycle of the governor in order to shield them from partisan politics. ${ }^{13}$

On the other hand, more autonomy (resulting from longer terms of appointment) could have increased the incentives for commercial bankers to expend resources in order to influence supervisory decisionmaking (Laffont and Tirole 1991; Martimont 1999). Resource expenditure aimed at influencing regulators may have undermined the soundness of the state banking system by promoting the issuance of charters to unsound banks, encouraging the postponement of bank

\footnotetext{
${ }^{11}$ Denying banking licenses and closing banks may run counter to the interests of constituents who helped elect the governor. A governor might retaliate against a particularly vigilant bank superintendent by not reappointing him or by forcing him to reconsider licensing or receivership decisions - potentially reducing the quality of state bank supervision.

${ }^{12}$ For example, when queried about weaknesses in the statutory provisions related to the office of bank commissioner, the superintendent for the state of Arkansas wrote, "The bank commissioner is appointed by the Governor, which in some instances is bound to have a political influence upon the operation of the bank department" (American Bankers Association 1929).

${ }^{13}$ As of 1929, supervisors' term lengths varied from two to six years; 28 states had four-year appointments. Gubernatorial terms varied between two and four years.
} 
examinations for weak banks, weakening oversight of bank risk management practices, or granting forbearance. Independent supervisory agencies may also be more susceptible to corruption and more concerned with implementing their own objectives rather than the public's (Chapman and Westerfield 1942; Barth, Caprio, and Levine 2001b; Djankov, La Porta, Lopez-deSilanes, and Shleifer 2002).

Policymakers have widely noted that the quality of supervision may have played a central role in worsening financial crises (Mishkin 1999; Corsetti, Pesenti, and Roubini 1998). The quality of supervision partly depends on having sufficient resources to hire and train competent bank examiners (Folkerts-Landau and Lindgren 1998; Neal 1942). If the examination staff is small in relation to the number of banks, even the most competent staff may be unable to monitor bank behavior, identify non-performing banks, and take appropriate regulatory intervention before banks became insolvent. ${ }^{14}$ As Table 2 indicates, banks per examiner varied widely across US states; difference in quality of supervision thus may help explain state bank suspensions.

Supervisory agencies lacking sufficient authority either to license or close banks may be incapable of preventing undercapitalized or mismanaged banks from entering the industry or incapable of removing cancerous banks from the system. The authority of the state bank supervisor to expedite the resolution of failed banks is one such power that varied across state banking departments (Table 2), and which could have influenced bank failure rates during the Depression. Having sole authority to liquidate banks is compatible with the interests of depositors and creditors as it leads to a faster resolution for claimants in contrast to a court-appointed receivership. Speedy resolution of claims can potentially reduce uncertainty and limit spillovers (or "contagion") from the failing institution to the rest of the system (Folkerts-Landau and

\footnotetext{
${ }^{14}$ If the decision to suspend a bank is viewed as a regulatory outcome, it is also possible that more vigilant supervision (as characterized here by state banking departments having more supervisors per bank) may have actually increased failures if examiners were concerned about negative spillovers. Moreover, if the examiners are paid poorly or are not full-time employees, then their incentives to uncover problems in banks may be weakened. This was a significant problem prior to 1913, when examiners were paid per examination, were not full-time employees of the state, and were expected to cover their own expenses. When the Fed and the OCC made bank examiners full-time, salaried employees of the state in 1913, and state regulatory agencies universally followed suit, these incentive problems disappeared (Robertson 1968, p.79; Committee on Branch, Group and Chain Banking 1931, vol.6, p.81).
} 
Lindgren 1998). A faster liquidation process could also limit credit-channel effects that operate through the assets tied up in failed banking institutions. ${ }^{15}$ Finally, the knowledge that resolution occurs quickly may reduce the opportunities for managers to engage in risk taking or expect forbearance once they are suspended (Fry 1995).

Insufficient authority to control the licensing or entry of new banks has also been linked to financial stability (Mishkin 2001). Some supervisors of state banking departments who did not have the sole power to deny or grant charters argued that this weakened their state banking systems. ${ }^{16}$ Many banking analysts of the 1920 s believed that an "overbanking" situation had arisen, not only from low capital requirements, but also from the lack of adequate power for supervisors to restrict charters (American Bankers Association 1935; Gruchy 1937; Neal 1942). When state bank supervisors were surveyed in 1934, several commented that having the authority to limit bank charters would have "aided in preventing many state bank failures in the last five years" (American Bankers Association 1934). On the other hand, vesting this power in the hands of a single regulator may lead to chartering decisions that are based on personal rather than public interests (Barth, Caprio, and Levine 2001b; Djankov, La Porta, Lopez-de-Silanes, and Shleifer 2002).

\section{ESTIMATION}

To estimate the effects of state-level differences in prudential supervision and regulation on state bank closures during the Great Depression, annual data on commercial bank suspensions from 1929-33 were collected for 48 states. ${ }^{17}$ The data include those commercial banks that

\footnotetext{
${ }^{15}$ Mason, Anari, and Kolari (2000) show that slow bank resolution involuntarily transforms liquid deposits into illiquid securities; during the Great Depression, this slowed the rehabilitation of insolvent debtors and the banking sector's ability to make loans, and affected bank depositors' consumption decisions.

${ }^{16}$ For example, the supervisor for the state of Delaware commented, "the principal elements of weakness [in state statutory provisions] consist in the lack of any definite restrictions which the department has over the establishment of new banks" (American Bankers Association, 1929). In contrast to the situation for many state banking authorities, the Comptroller's office had established a system as early as 1909 that permitted a great degree of control over the granting of new charters for national banks; its decisionmaking process included evaluating economic criteria of communities where new banks were proposed.

${ }^{17}$ Data for commercial bank failures (excluding mutual savings banks and private banks) are from the Federal Reserve Board Bulletin, September 1937. "The figures for 1933 comprise banks suspended before
} 
suspended their operations either temporarily or permanently, unless the closure was due to a special bank holiday, in which case it is counted only if it remained closed. ${ }^{18}$

The dependent variable $\left(S R S B_{i t}\right)$ is the suspension rate of state-chartered, non-Fedmember banks (the set of commercial banks regulated and supervised by state banking departments), and is defined as the number of state-chartered banks in state $i$ suspended for a given year $t$ divided by the total number of state banks existing as of June 30 of that same year (expressed in percentage terms). ${ }^{19}$ Equation 1 is estimated as follows:

(1) $S R S B_{i t}=\beta_{0}+\beta_{1} B_{R A N C H}+\beta_{2} C A P_{i t}+\beta_{3} R E S_{i t}+\beta_{4} S U P T E R M_{i}+$

$$
\beta_{5} \text { BANK/EXAM }_{i}+\beta_{6} \text { CHARTER }_{i}+\beta_{7} \text { LIQUIDATION }_{i}+\beta_{8} \text { FRNB }_{i t}+\varepsilon_{i t} .
$$

$C A P_{i t}$ is the minimum capital required of banks in small municipalities (measured in thousands of dollars). $R E S_{i t}$ is the reserve requirement expressed as a percentage of country-bank demand deposits, and $B R A N C H_{i t}$ is the percentage of state banks with branches. The length of a supervisor's term $\left(S U P T E R M_{i}\right)$ is measured in years and the number of banks per examiner $\left(B A N K / E X A M_{i}\right)$ is the value for June 1929. Liquidation authority (LIQUIDATION) and licensing authority (CHARTER) are indicator variables where positive values reflect states that grant their

the banking holiday, licensed banks suspended or placed on a restricted basis following the bank holiday, unlicensed banks placed in liquidation or receivership, and all other unlicensed banks which were not granted licenses to reopen by June 30, 1933" (Federal Reserve Bulletin, September 1937, p.866). The total number of banks fitting one of these criteria is 4,000 .

${ }^{18}$ To be sure, there are differences between suspended and closed banks. This paper follows the Federal Reserve's convention: state bank suspensions comprise "all banks closed to the public, either temporarily or permanently by supervisory authorities or by the banks' boards of directors on account of financial difficulties, whether on a so-called moratorium basis or otherwise, unless the closing was under a special bank holiday declared by civil authorities. If a bank closed under a special holiday declared by civil authorities and remained closed only during such holiday or part thereof, it has not been counted as a bank suspension" (Federal Reserve Bulletin, September 1937, p.866). Banks that become insolvent and are placed under receivership or that liquidate their assets voluntarily might properly be termed failures, and are a subset of suspensions. Federal Reserve data at the state level, however, do not permit one to distinguish between failures, temporary suspensions, and bank mergers. The data used here potentially overstate the true number of failures for state banks, but unless there is some systematic reason to believe that there are important regional differences between failures and suspensions, the hypotheses tested should not be adversely affected if suspended banks are included. Calomiris and Mason (2000, p.30) point out that this distinction in theory can be important, but they do not find that their results for the 1930-32 sample period are sensitive to the choice of failures versus suspensions.

${ }^{19}$ Data on the number of banks are from Board of Governors (1959). 
supervisors the authority to liquidate banks without first having a court appoint a receiver and states that give sole licensing authority to the supervisor. ${ }^{20}$ Summary statistics for the regulatory variables are shown in Table 2. The initial identifying assumption is that the regulatory and supervisory aspects of banking are uncorrelated with the random element of bank failures.

If some of the cross-state variation in failure rates for state-chartered banks is attributable to factors common to all commercial banks within a state, omitted variables bias is a potential problem. However, including factors such as state economic conditions can potentially introduce simultaneous equations bias (that is, economic conditions can influence bank failures and vice versa). Previous studies examining the effects of regulation on bank failures have not adequately addressed the issue of simultaneity bias. ${ }^{21}$ A standard treatment would be to develop a system of equations to explain the relationship between economic conditions and bank failures; however, due to data limitations, it is difficult to find instruments to identify both equations. As an alternative to the simultaneous equations approach, we take advantage of the unique bifurcated nature of regulation and supervision in the U.S. dual banking system and include the failure rate for national banks at the state level as an additional regressor. ${ }^{22}$ Conditioning on the national bank failure rate $\left(F R N B_{i t}\right)$ will control for statewide time-varying effects common to all commercial

\footnotetext{
${ }^{20}$ All supervisory variables (length of supervisors' terms, number of examiners per bank, charter and liquidation authority) are from American Bankers Association (1929). Supervisory characteristics are based on surveys conducted during the first half of 1929. Data on reserve requirements are from the Federal Reserve Bulletin (1929-1934). The rate on demand deposits is used since it was the most liquid form of bank deposits, and most susceptible to depositor withdrawal. Data on branching laws and percentage of branches are from Federal Reserve Bulletin (various issues, 1929-1934). Data for capital requirements are from Polk's Bankers Encyclopedia (various issues, 1929-1933). In some states, capital requirements varied according to the size of the municipality where the bank was established. Where this was true, the capital requirement for the smallest defined municipality was used (usually 3,000 people).

${ }^{21}$ For example, Wheelock $(1995$, p.30) suggests that his results on state bank regulation (he does not consider supervision) do not account for the feedback between the severity of the Great Depression in a state and bank failures in that state, and therefore suffer from simultaneous equations bias. And in their analysis of recent country data, Barth, Caprio, and Levine (2001b) do not fully address this issue.

${ }^{22}$ National bank failures are those banks chartered by the OCC that were placed in receivership; it does not include banks that suspended operations and later reopened, or those that were later absorbed. Treating the commercial bank data in a disaggregated fashion, where national bank failures are used merely as a control variable for state-specific distress, avoids the difficulty of meshing the state bank suspension series with the national bank liquidation series. Previous studies, such as Wheelock (1995) and Gambs (1977), use aggregate data on all commercial banks, and make no attempt to adjust for this discrepancy. See Calomiris and Mason (2000) for a further discussion of this issue.
} 
banks, such as business or agricultural distress. Since the regulatory and supervisory characteristics that we are interested in explaining only applied to state banks, there is no direct effect from these variables on national banks, which were solely regulated and supervised by the OCC. Although it is possible that specifications including the failure rate for national banks "over control" for common state effects, we are confident that this does not result in upwardly biased estimates of the impact of regulation and supervision on state bank suspensions. Moreover, including the failure rate of national banks has the additional advantage of conditioning statechartered bank failure rates on a wider set of state influences than measures such as unemployment, business failures, or changes in personal income.

\section{ANALYSIS OF STATE BANK SUSPENSIONS}

Table 3 displays results from pooled, weighted least squares (WLS) regressions for the 1929-33 period. ${ }^{23}$ The weights are the square roots of the number of banks in each state; EickerWhite heteroskedasticity-consistent standard errors are reported. Column 1 displays the results for a baseline regression where we regress the state nonmember failure rate on differences in regulation and supervision for these banks as well as exogenous state characteristics such as population density and the shares of a state's population that is urban, that is employed in manufacturing, retail, wholesale, and agriculture, respectively. Most of the coefficients for the regulatory and supervisory variables enter with the expected signs and are significantly different from zero at standard confidence levels. Column 2 includes the national bank failure rate to control for state-specific factors affecting all banks during the Great Depression (as in Equation 1). As expected, the R-squared improves, and the coefficients are similar to those reported in column 1, (although somewhat smaller in size), even though the national bank failure rate absorbs a considerable amount of variation across states.

\footnotetext{
${ }^{23}$ The initial downturn in the U.S. economy occurred in 1929. Given the dramatic changes in federal regulation that occurred under the first Roosevelt administration (including the creation of deposit insurance), and the subsequent decline in failure rates in 1934, the last year included is 1933.
} 
States granting their supervisors the sole authority to liquidate state banks had failure rates that were approximately 3.5 percentage points lower. As section 2 suggested, endowing supervisors with this authority may have improved financial stability by reducing: (1) severity of credit-channel effects that are associated with unresolved bank failures; (2) contagion to the rest of the financial system; and (3) the likelihood that banks engage in risk taking or expect forbearance. The negative coefficient is also consistent with the concerns expressed by state bank regulators and by the Fed, which believed that giving state bank supervisors liquidation authority would lead to a faster liquidation process and promote a better technique for carrying out liquidation (Board of Governors 1931, vol.6, p.91). ${ }^{24}$

The positive and statistically significant coefficient on the length of the supervisor's term suggests there are tradeoffs in designing supervisory structures. Longer terms for supervisors reduced the influence of the executive branch on state banking departments in the 1920s, but they also made it more attractive for representatives of the banking industry to lobby superintendents and gain influence over their decisions. An additional year in office raised the failure rate for state-chartered banks by roughly 1.6 percentage points. (The range of term lengths varied from 2 to 6 years.) The positive sign is consistent with the theoretical literature emphasizing how autonomy gives regulators "enforcement freedom": longer terms may weaken the incentives for regulators to act independently of individual bank interests and potentially induce them to use their discretionary powers (delaying examinations, granting forbearance, or issuing charters) at the expense of systemic safety. Consistent with Barth, Caprio, and Levine (2001b) regulators could have used their offices to extract personal benefits or even collect bribes in a manner inconsistent with systemwide stability. Vickers (1994, pp.34-5) describes the situation in Florida in the 1920s as one where bankers knew how to prey on Comptroller Amos's "weakness and greed" by providing him and his examiners with unsecured loans. "Promoters eagerly sought

\footnotetext{
${ }^{24}$ As the Colorado state superintendent wrote, "The administration of banks in liquidation may be handled at less expense and more diligently wherein it is not necessary to constantly refer matters to the courts, which in many instances are extremely slow in the determination of important matters"(American Bankers Association 1929).
} 
bank charters, which regulators willingly provided. The newly sanctioned bankers then used depositors' money to fund their own projects. And with their new source of money, they bought regulatory protection by making loans to bank officials." Comptroller Amos was eventually indicted by a Palm Beach County grand jury for gross malpractice. Meanwhile, Florida experienced numerous failures throughout the 1920s and eventually a severe panic in 1929.

States that granted supervisors the sole authority to issue charters also experienced suspension rates that were roughly 1.5 percentage points higher, although the result is only weakly statistically significant. Supervisors with full discretionary authority over licensing decisions may have destabilized the state banking system by granting charters to banks whose applications had been rejected by the OCC or by setting chartering criteria too low. Consistent with a corruption interpretation of this coefficient, some bank superintendents from the 1920s have acknowledged that their departments were susceptible to industry influence. As the bank supervisor of Oklahoma described, "For a period of about 3 years from 1919 until 1922 graft and corruption played a dominant role in the operation of the State Banking Department. Charters were to be had at a price" (Neal 1942).

The positive and statistically significant coefficient on reserve requirements is consistent with the theoretical literature, which argues that prudential regulations can lead to higher failure rates if they induce banks to change the composition of their portfolios or reduce the incentives for depositors and investors to monitor bank behavior. ${ }^{25}$ The higher implicit tax induced banks to increase their share of risky assets (relative to riskless) in order to increase return.

A 10-percentage point increase in the number of state banks with branches (approximately a one-standard-deviation increase) reduced suspension rates by approximately 1.3 percentage points. The negative coefficient suggests that branching stabilized state banking systems by introducing competition and weeding out inefficient banks through mergers or closures, or that branching (even within a state) enabled banks to lower their risk through

\footnotetext{
${ }^{25}$ Although it is not a definitive test, since the positive sign on the reserve requirement coefficient is robust to the inclusion of delegated monitoring (the number of state banks per examiner), it seems that the regression is most likely capturing the portfolio response of banks to higher reserve requirements.
} 
diversification opportunities. Alternative definitions of branching do not alter this basic finding. ${ }^{26}$ This finding is consistent with Wheelock (1992) and Rose and Scott (1978), who find that branch banking at the state level had stabilizing effects in other decades, and stands in contrast to studies that have argued that branching has little or no stabilizing effect (Wicker 1980; Carlson 2004).

Column 3 shows that the estimated coefficients on the regulatory and supervisory variables do not appear to be sensitive to the inclusion of either state-specific characteristics of the banking industry that may also influence banking stability or year dummies (where 1933 is the omitted year). ${ }^{27}$ After controlling for other factors, the coefficients on these variables (not reported in the tables) enter with the correct predicted signs, but are not significantly different from zero at standard confidence levels. Column 4 redefines the dependent variable to be the difference between state and national bank failure rates. This specification may be preferable if feedback between the national failure rates is somehow affecting the state regulatory and supervisory variables. One reason this could be a problem is if competition in laxity existed among regulatory authorities. For example, wishing to circumvent federal restrictions on branching, national banks may have formed chain or group banking associations. ${ }^{28}$ Competition

\footnotetext{
${ }^{26}$ We also tested (1) the number of total branches of state banks divided by total state banks; (2) an indicator variable where positive values correspond to those states that permitted branch banking of any sort; and (3) an indicator variable where positive values correspond only to those states had legalized statewide branching. The sign and statistical significance on the branching coefficient were robust to these alternative proxies.

${ }^{27}$ For banking industry controls, we included: (1) a measure of concentration, since more concentrated banking systems may enable banks to coordinate responses to crises and build up cash reserves or a strong capital surplus (Demsetz 1973, 1974; Grossman 1994); (2) average deposits per state bank, since bank size has been linked to greater diversification opportunities, economies of scale, and larger surpluses and profits (Calomiris and Mason 2000; Grossman 1994; and Wheelock 1995); (3) the average riskiness of a state bank's portfolio (Calomiris and Mason 2000; Carlson 2004); and (4) the average capital-asset ratio for state banks. The measure of concentration is the share of deposits in the largest four state banks in 1929, calculated using data from Polk's Bankers Encyclopedia Co. (1929) and Board of Governors, Federal Reserve System (1959). Risky assets for state banks are calculated as the percentage of assets that are neither cash nor government bonds. Data on different types of assets, deposits, and on capital are from Board of Governors, Federal Reserve System (1959). We also considered two alternative measure of banks: (1) the percentage of a state's state-chartered banks located in counties where the average deposits per bank is in the lowest third of all counties in the United States and (2) average assets per bank. The first was calculated using data from a data file from the ICPSR authored by the Federal Deposit Insurance Corporation (1960). We also considered an alternative for concentration: people per bank. The results presented in Table 3 were not sensitive to these alternative definitions.

${ }^{28}$ Group banking, or collections of banks linked together through holding companies, gained prominence in the 1920s in response to restrictions on branching, and were used as alternative means for achieving economies of scale and greater portfolio diversification. Groups and chains were most common in the
} 
in laxity might have also been a problem in setting prudential regulations. If the Federal Reserve or OCC denied a bank a charter, it might seek a state charter instead; state banking authorities might be willing to grant it one in order to expand the number of banks under their jurisdiction. Regulators complained about this competition over chartering during the first quarter of the century (Board of Governors 1931, vol.6, p.85). Although competition in laxity was a concern of regulators in the 1920 s and 1930 s, the coefficients on the regulatory and supervisory variables shown in column 4 do not appear to be sensitive to our test for it.

Because of countervailing effects, even well-intentioned regulators may have experienced greater suspension rates. (A correlation matrix of bank regulation and supervision is shown in Table 4.) That is, while state authorities may have wanted to improve stability by changing the regulatory environment, increasing the reserve requirement by one standard deviation while simultaneously extending state branch banking (by one standard deviation) would have reduced the stability and diversification benefits coming solely from branch banking. States nevertheless would have still seen their suspension rates drop by approximately 0.5 percentage points. Giving supervisors more authority in general also had offsetting effects since the effects of granting supervisors the authority both to liquidate banks and charter banks moved suspension rates in the opposite direction. Nevertheless, simultaneously giving both powers to supervisors reduced suspension rates by around 2 percentage points. Granting liquidation authority and permitting branch banking thus seem particularly important in driving bank stability.

We can also get a sense of the economic significance of the results by considering what alternative regimes would have meant for stability. For example, what if the dual banking system had been abandoned and states had been forced to adopt the regulatory and supervisory standards that applied to national banks? This would have been a mixed blessing for states since the OCC's regulatory and supervisory regime was not necessarily "best practice" in that it minimized

Midwest and South where prohibitions on branch banking were widespread (Board of Governors 1931, vol.7, 1931, p.210). According to a survey conducted by the Federal Reserve Committee on Branch, Group, and Chain Banking, the majority of banking groups surveyed would have preferred to be part of branching systems rather than groups if the law permitted it (Board of Governors 1931, vol. 7, p.72). Of course, some of those groups in the survey were prohibited by state law rather than federal law. 
failures. The Office of the Comptroller was appointed by the President, had both liquidation and charter authority, and had more examiners relative to banks at his disposal than in many states (15.5 banks per examiner in 1929). The OCC prohibited statewide branch banking, reserve requirements were set at $7 \%$, and minimum charter capital was $\$ 25,000$. The annual suspension rate for a state bank with national bank regulatory and supervisory characteristics, holding all else equal (and using regression coefficients from column 3), would be 2.3 percentage points lower for the 1929-33 period. ${ }^{29}$ We could instead examine what would happen if all states had moved in the direction of what the regressions reveal as "best practices" of the state regulators. If we adjust the regulatory and supervisory variables by one standard deviation in the direction of "best practice," the annual suspension rate would have fallen by 5.8 percentage points.

Finally, we tried a variety of other specifications, including count data analysis, a log proportions model, constraining our specification to the "between" estimator (a regression on group means), and restricting the sample to 1929-32 since President Roosevelt declared a banking holiday in $1933 .^{30}$ In each of these alternatives (not shown), the results for the key regulatory and supervisory variables were quite similar to those presented in Table 3.

\section{ALTERNATIVE MEASURES OF DISTRESS AND ADDITIONAL SENSITIVITY TESTS}

\section{A. Bank deposits and assets in suspended banks}

The previous section focused on bank suspensions as a measure of state banking distress since numerous suspensions could indicate that a banking system has expanded in an unhealthy fashion (perhaps due to poor regulation or supervisory practices) or that correspondent

\footnotetext{
${ }^{29}$ The annual average suspension rate over the period is $11.03 \%$.

${ }^{30} 1933$ may not be fully comparable with those of the previous years as the precise status of a bank was difficult to determine due to state bank holidays and the national bank holiday in March. The bank suspension figures for 1933 that were used in the other regressions included banks suspended before the holiday, banks placed in liquidation or receivership, and all unlicensed banks that were not granted licenses to reopen by June 30,1933 (the time at which supervisory authorities had nearly completed their examinations of nearly all the banks not granted licenses immediately after the holiday). For count data analysis, we used a negative binomial distribution (due to overdispersion in the data) and including the log number of banks to account for the size of the "at-risk population."
} 
relationships played an important role in spreading the crisis. Analyzing total assets or deposits in suspended or failed institutions may shed light on how well depositors were protected or whether particular regulatory and supervisory practices were better at limiting the size of failures (measured in terms of either assets or deposits). That is, lower suspension rates may indicate how well regulators protected banks, whereas lower shares of total deposits in suspended institutions may give a better sense of how effective regulators were at providing depositor protection. Table 4 therefore re-estimates equation (1) using the (log) annual share of total state deposits located in suspended state-chartered banks or the (log) annual share of total loans and investments in suspended state-chartered banks (our measure of assets) as the dependent variable. ${ }^{31}$

Using these alternative dependent variables does not dramatically change the signs or levels of significance on the key explanatory variables. In addition to state economic conditions, supervisory term length $(+)$, the extent of branch banking $(-)$, and reserve requirements $(+)$ seem particularly influential in driving the size of state bank suspensions, measured either in terms of assets or deposits. There are two noteworthy differences compared to the results using suspension rates as the dependent variable: liquidation authority is now only marginally statistically significant and the coefficient on banks per examiner has the correct predicted sign and is marginally significant. First, the marginally statistically significant coefficient on liquidation authority suggests that granting supervisors this authority was likely more important for managing the spread of suspensions via correspondent relationships rather than limiting their magnitude. Second, the positive sign and marginal statistical significance on the banks per examiner coefficient in Table 5 suggests that supervisory resources may have more bang for the buck in mitigating the size of failures rather than the spread of them. Facing limited resources, states may have focused on larger financial institutions. (This stands in contrast to the somewhat

\footnotetext{
${ }^{31}$ The residuals on these two measures were not normally distributed, so we use logs. In cases, where the value was zero, we either dropped the observations or changed them to the arbitrarily small value of 0.0001 . The table displays the latter, although the results do not appear sensitive to the choice. Data on loans and investments and deposits in suspended banks are from Federal Reserve Bulletin, September 1937.
} 
surprising result of Table 3: that having more examiners seems to have mattered very little for mitigating bank suspensions. ${ }^{32}$ )

The last two columns of Table 5 test additional aspects of the quality of supervision. We include the pay of examiners relative to what they could earn in the private sector, since large differences in compensation between bank examiners and commercial bankers have been associated with conflicts of interest, excessively rapid turnover of qualified staff, and inability to attract capable and qualified staff (Folkerts-Landau and Lindgren 1998). ${ }^{33}$ States that paid their examiners more could have done a better job of examining banks and minimizing the magnitude of the suspensions. We also include assets per bank examiner (as of June 1929) since larger state banks may have required proportionately more supervisory resources to uncover problems and resolve them.

All three variables measuring supervisory resources enter with the predicted signs. Consistent with numerous statements by state supervisors and the Fed, the negative sign on the wage differential suggests paying bank examiners more (relative to what they could earn in industry) reduced turnover, attracted more qualified employees, and increased tenure length thus improving the quality of supervision. ${ }^{34}$ The coefficients on banks per examiner and assets per examiner are also statistically significant at around the $10 \%$ level. The positive signs on these variables suggest that hiring more examiners may have enabled examiners to conduct more

\footnotetext{
${ }^{32} \mathrm{We}$ examined the sensitivity of this result in several ways. First, we looked at whether the coefficient was driven by any outliers in the number of banks per examiner. The data for June 1929 range from 1.5 to 75.7 banks per examiner. We re-estimated column 3 of table 3, dropping the three states with the highest values (Minnesota, Georgia and Kansas), one at a time and altogether; the sign and statistical significance of the coefficient did not change. We then examined the DFBETAs, and did not discover any outliers for banks per examiner. We also estimated regressions using two other alternative definitions for supervisory resources: assets/deposits in state banks per examiner and state population to total examiners. The sign did not change and statistical significance of the coefficient did not appear sensitive to using these alternative definitions for supervisory resources where the dependent variable was the suspension rate.

${ }^{33}$ Regulators' salaries are from American Bankers Association (1929), and bank executives' average salaries are calculated using data from US Census of Business (1936). The difference between supervisor wages and bank executives yielded similar results to those reported in Table 4 . The finance industry salary data are for 1935, the first year that a census of the banking industry was conducted in the U.S.

${ }^{34}$ When surveyed in 1929, at least 11 state bank supervisors explicitly mentioned that salaries were an important factor in attracting and retaining competent and qualified examiners. Some even suggested linking their pay to that of vice-presidents and treasurers of large banking institutions (American Bankers Association 1929). See also Board of Governors (1931, vol.6, pp.82, 91-3).
} 
thorough examinations of banks and better control the scope of bad loans and investments (assets). Moreover, states that committed more resources to their departments by having more examiners relative to the number or size of banks were better able to protect the money of depositors by reducing the amount of suspended deposits. This result is consistent with the view that examiners added value by focusing on large failures, thereby protecting depositors' claims.

\section{B. Endogeneity of regulation}

It is possible that banking regulations are endogenous and therefore correlated with the error term. The public interest theory of regulation supports the notion that endogeneity may be present because banking distress galvanizes lawmakers to change regulations where the social costs of bank failures are greatest (Kroszner and Strahan 1999, 2001). Recent crises in emerging market and transitional economies also support the idea that regulations are often forged in response to crisis (Calomiris and Powell 2001; Neyapti and Dincer 2000). ${ }^{35}$

To deal with the possibility that state bank regulations are endogenous, we first construct instruments for branching laws and the prudential regulations, recognizing that regulations were shaped by the political economy of the period, and were hence the product of interest-group influence and public concern over the failure of many rural banks in the 1920s (Mitchener 2001). In states where they were more effectively organized, interest groups (representing bank customers, competitors of banks, and the banks themselves) were successful in obtaining banking regulations (such as prohibitions on branch banking) consistent with their private-interest motives. ${ }^{36}$ Moreover, states that experienced severe rural bank crises during the 1920 s or that had experimented with state deposit insurance systems (and had seen these systems fail) were more

\footnotetext{
${ }^{35}$ A Hausman specification test failed to reject the null hypothesis that the regulatory variables are exogenous at standard significance levels. Comparing the constrained and unconstrained models, the Chisquared statistic $=0.15$.

${ }^{36}$ Although branching activity expanded in states where it was permitted, the number of states permitting statewide branching did not grow in the 1920s, in part due to the lobbying of small, unit bankers to prevent its spread (Board of Governors 1931, vol.9).
} 
likely than other states to respond by changing prudential regulations such as reserve requirements.

As the Appendix describes in more detail, we use political and historical factors as instrumental variables for 1929 regulations. The R-squared in the first-stage regressions for capital requirements, reserve requirements, and states prohibiting branching are $0.22,0.65$, and 0.40 , respectively, and the signs on most variables in the first stage are as predicted. ${ }^{37}$ Column 1 of Table 6 shows that, after instrumenting, the coefficients on the supervisors' length of term, the power to liquidate insolvent banks and charter banks, and branch banking maintain their statistical significance, although the coefficient on the reserve requirements is no longer statistically significant. To test explicitly whether banking distress of the 1920 s played a more direct role in influencing financial stability during the Depression, Column 2 includes the percentage of bank failures averaged over the 1921-28 period in the IV regression specification. ${ }^{38}$ If Depression-era failures were a continuation of the banking distress of the 1920s, then the sign on this coefficient will be positive and statistically significant. However, despite entering with the correct expected sign, the coefficient is statistically insignificant at conventional levels. We can conclude that the failures of the 1920s did not have an independent impact on those that occurred during the Depression once regulation, supervision, and industry structure are taken into account.

As a second method for dealing with the endogeneity of regulation, we re-estimate equation (1) using the 1924 values of the prudential regulations and branching laws; endogeneity should no longer be a problem since the regulatory characteristics are predetermined. As Column 3 shows, the results are similar to those reported in Table 3. The coefficient on reserve

\footnotetext{
${ }^{37}$ For example, the first-stage results show that: (1) the coefficient on the share of small banks in a state is negatively associated with the states permitting statewide branching, indicating that small, unit bankers wanted to protect their geographical monopolies; (2) the coefficient representing inter-industry competition is positive for the capital requirement regression since insurers wanted to block small banks from brokering insurance (which they were legally permitted to do beginning in the 1920s); and (3) states passed higher reserve requirements in response to experiments with failed deposit insurance schemes.

${ }^{38}$ It is possible, for example, that the banking distress of the Depression was merely a continuation of the rural distress of the 1920s. This argument has been widely discussed in the literature, but has not been resolved (Friedman and Schwartz 1963; Temin 1976; Stauffer 1981; White 1983). Data on bank failures from the 1920s are computed from Federal Reserve Bulletin (September 1937).
} 
requirements is once again statistically significant at conventional levels and branch banking appears to have lowered suspension rates. Overall, the robustness checks in this section do not alter the basic findings.

\section{CONCLUDING REMARKS}

The dual banking system of the $19^{\text {th }}$ century locked in a regulatory structure that encouraged institutional experimentation. States responded by creating banking departments that enforced an array of prudential standards and operated with widely different powers and resources. This was not necessarily a recipe for disaster as experimentation could have led to the evolution of better standards. But, as is the case today, banking laws in the 1920s emerged in response to the lobbying of interest groups (banks, their customers, and their competitors) and in response to earlier periods of banking instability. Small, unit bankers had derailed efforts to overhaul the banking system at the national level and blocked interstate banking. Only in states where unit banks had a weaker presence and where competition with national banks was intense were lawmakers able to pass intrastate branching laws. Capital requirements and reserve requirements were likewise influenced by the interplay of private and public interests. The experience of state banks during the Depression suggests that implementing "best-practice" regulatory and supervisory arrangements across borders and creating a unified regulatory framework may prove to be intractable. Pre-existing regulatory structures create powerful incentives for private interests to protect regulations that undermine stability.

The give-and-take of the political process at the state level permitted the evolution of many poorly structured regulatory and supervisory regimes, and some states ended up adopting regulations that undermined the stability of their banking systems. For example, those states that prohibited branch banking (in part due to the influence of small, unit bankers) and that responded to the banking crisis of the 1920 s by instituting strict reserve requirements experienced higher failure rates for their state-chartered financial institutions during the Great Depression. Moreover, 
some states' banking departments were slow to institute the procedures, policies, and features of the older, more established Comptroller's Office in their banking departments, while others adopted an institutional design that enhanced their ability to compete with the national regulators. Those states that had lengthened the terms of their banking supervisors in order to insulate regulators from political influence also made it more attractive for the banking industry to lobby bank supervisors with discretionary authority. Longer term-lengths had counterproductive consequences for financial stability as these states experienced higher state bank suspension rates of assets from 1929-33. On the other hand, those states that granted supervisors the authority to liquidate banks without first appointing a court receiver avoided the deleterious effects of delayed liquidation and experienced greater stability. Finally, states that endowed their supervisors with more resources were better able to manage the size of bank suspensions and protect depositor claims. 


\section{APPENDIX. INSTRUMENTAL VARIABLES FOR BANK REGULATIONS}

Competing theories of regulation have been shown to be good predictors of regulatory outcomes (Kroszner and Strahan 1998). To capture elements of the private-interest theory or economic theory of regulation (where outcomes are determined by interest groups who expend resources for private gain), competition between state banks of different sizes (intra-industry competition) and competition between banks and non-bank financial service providers (interindustry competition) are used as instrumental variables. ${ }^{39}$ Small banks (often rural in location) had local monopolies based on geography in the $1920 \mathrm{~s}$, and according to this theory of regulation, would have spent resources on influencing politicians who control entry and exit into banking markets (e.g. capital requirements and branching laws). ${ }^{40}$ And insurance companies in the $1920 \mathrm{~s}$ may have been willing to expend resources to restrain bank competition because of the growth of group banking (which enabled banks to offer an array of services including investment and insurance underwriting) and legal changes that permitted commercial banks in some states to broker insurance in small towns. The private-interest theory of regulation also suggests that small firms, dependent on bank credit, would favor the removal of restrictions on branching or high capital requirements if it reduced market power or improved efficiency and resulted in the delivery of lower-cost loans. The percentage of manufacturing establishments in the state with fewer than 20 employees in 1919 is therefore included to capture the influence of the small

\footnotetext{
${ }^{39}$ The percentage of a state's state-chartered banks located in counties where the average deposits per bank was in the lowest third of all counties in the U.S. in 1920 is used to capture the influence that small banks had on 1929 regulatory outcomes. Data on the share of small banks are computed from an ICPSR data set originally authored by the Federal Deposit Insurance Corporation (1960). Employment in the insurance industry relative to the total for insurance and banking (measured in percentage terms) in 1919 is included to proxy for inter-industry competition. Figures for 1920 employment in insurance and banking are the revised series published in the 1930 U.S. Census of Population. Employment in the insurance industry includes both officers and insurance agents. While there were certainly large national insurance companies operating across state borders in the 1920s, the presence of smaller insurance firms and the inclusion of agents in the employment-based measure led to considerable variation in insurance employment across states. The measure of interest-group influence is based on data from the beginning of the 1920s, since changes in bank regulations during the decade could have altered the relative size or influence of interest groups.

${ }^{40}$ White (1983), Kroszner and Strahan (1998), Abrams and Settle (1993), and Economides, Hubbard, and Palia (1996) argue that small banks are concerned with the erosion of economic rents if larger urban banks are allowed to compete with them directly through branching.
} 
business lobby on regulatory outcomes. ${ }^{41}$ Interaction terms were also included to proxy the response of interest groups to sector-specific stresses. ${ }^{42}$

To capture elements of the public-interest theory of regulation, where, for example, legislators would respond to public concern over the safety or solvency of the banking system by raising capital or reserve requirements, the average failure rate for state banks over the period 1921-28 is used as an instrument. A dummy variable for the eight states that experimented with government-created liability-insurance schemes in the 1920s is also included since state legislators may have responded to the failure of these systems and their high social costs by changing other prudential regulations. ${ }^{43}$ Finally, to reflect political-institutional theories of regulation, the number of years from 1921-28 where one party occupied both chambers of the state legislature and the governorship and the number of years from 1921-28 that Democrats controlled the upper house and the governorship (reflecting differences in party ideology) are used as instrumental variables. ${ }^{44}$

\footnotetext{
${ }^{41}$ Data on small firms are revised from those reported in 1920, and are from the 1930 U.S. Census of Manufactures.

${ }^{42}$ The percentage of small state banks was interacted with the bank failure rate for state banks in the 1920s to see if the influence of small banks changed as a result of the size of this lobby. The variable proxying for the importance of small industry was multiplied by the (1920-28) average business failure rate. Lacking data on failure rates by state for insurance companies, the measure for relative insurance industry employment was squared to capture the dynamic-lobbying effects of insurance companies.

${ }^{43}$ North Dakota, South Dakota, and Nebraska made membership in the system compulsory whereas Kansas, Oklahoma, Texas, Mississippi, and Washington did not.

${ }^{44}$ Since the number of years Democrats controlled the lower house is highly collinear with Democratic control of the upper house (0.94), the lower house is excluded from the regressions. Data on political control of the legislative and executive branches are from the ICPSR data file authored by Burnham (1985). Nebraska's unicameral legislature was treated as an upper house chamber. The results do not appear sensitive to the inclusion of Nebraska. Data from ICPSR are given only in those years for which a new election was held. Most states held elections every other year; however, some held elections only every third or fourth year. New Jersey and New York held elections every year.
} 


\section{REFERENCES}

Abrams, Burton A. and Russell F. Settle. 1993. "Pressure-Group Influence and Institutional Change: Branch-banking legislation during the Great Depression." Public Choice 77: 687-705.

American Bankers Association. 1935. The Bank Chartering History and Policies of the United States. New York: Economic Policy Commission, ABA.

American Bankers Association. 1934. Survey on State Bank Supervision. Washington, DC: ABA, State Bank Division.

American Bankers Association. 1929. Survey on State Bank Supervision. Washington, DC: ABA, State Bank Division.

Barth, James R., Gerard Caprio, and Ross Levine. 2001a. "The Regulation and Supervision of Banks around the World: A New Database." In Brookings-Wharton Papers on Financial Services, edited by Robert E. Litan and Richard Herring, pp. 183-240. Washington, DC: Brookings Institution Press.

Barth, James R., Gerard Caprio, and Ross Levine. 2001b. "Bank Regulation and Supervision: What Works Best?" Working Paper. World Bank, Washington, DC.

Benston, George. 1986. "Federal Regulation of Banking: Historical Overview.” In Deregulating Financial Services: Public Policy in Flux, edited by George G. Kaufman and Roger C. Kormendi, pp. 1-47. Cambridge, MA: Ballinger Publishing.

Benston, George J. and George C. Kaufman. 1994. "The Intellectual History of the Federal Deposit Insurance Corporation Improvement Act of 1991." In Reforming Financial Institutions and Markets in the United States: Towards Rebuilding a Safe and More Efficient System, edited by George G. Kaufman, pp.1-17. Boston, MA: Kluwer Academic Publishers.

Bernanke, Ben and Harold James. 1991. "The Gold Standard, Deflation, and Financial Crises in the Great Depression: An International Comparison.'In Financial Markets and Financial Crises, edited by R. Glenn Hubbard, pp. 33-68. Chicago, IL: University of Chicago Press.

Besanko, David and George Kanatas. 1993. Credit Market Equilibrium with Bank Monitoring and Moral Hazard." Review of Financial Studies 6(1): 213-32.

Blum, Jurg. 1999. "Do capital adequacy requirements reduce risks in banking?" Journal of Banking and Finance 23: 755-71.

Board of Governors, Federal Reserve System. 1959. All-Bank Statistics: United States, 18961955. Washington, DC: Federal Reserve System.

Board of Governors, Federal Reserve System. Various issues. Bulletin. Washington, DC: Federal Reserve System.

Board of Governors, Federal Reserve System. 1931. Report of the Committee on Branch, Group, and Chain Banking Committee. Volumes 1, 6, 7, and 9. Washington, DC: Board of Governors. 
Boot, A. and S. Greenbaum. 1993. "Bank Regulation, Reputation, and Rents Theory and Policy Implications." In Capital Markets and Financial Intermediation, edited by C. Mayer and Xavier Vives, pp. 262-85. Cambridge: Cambridge University Press.

Burnham, W. Dean. 1985. "Partisan Division of American State Governments, 1834-1985." [Computer file]. Conducted by Massachusetts Institute of Technology. ICPSR ed. Ann Arbor, MI: Inter-university Consortium for Political and Social Research [producer and distributor].

Calomiris, Charles W. 2000. U.S. Bank Deregulation in Historical Perspective. Cambridge: Cambridge University Press.

Calomiris, Charles W. and Joseph R. Mason. 2003. "Consequences of Bank Distress during the Great Depression.” American Economic Review 93(3): 937-47.

Calomiris, Charles W. and Joseph R. Mason. 2000. "Causes of U.S. Banking Distress during the Depression.” Working Paper No. 7919. National Bureau of Economic Research, Cambridge, Mass.

Calomiris, Charles W. and Andrew Powell. 2001. "Can Emerging Market Bank Regulators Establish Credible Discipline? The Case of Argentina, 1992-99.” In Prudential Supervision: What Works and What Doesn't, edited by Frederic S. Mishkin, Chicago, IL: University of Chicago Press.

Carlson, Mark. 2004. "Are Branch Banks Better Survivors? Evidence from the Depression Era." Economic Inquiry 42(1): 111-26.

Chapman, John M. and Ray B. Westerfield. 1942. Branch Banking: Its Historical and Theoretical Position in America and Abroad. New York, NY: Harper and Brothers.

Corsetti, Giorgio, Paolo Pesenti, and Noriel Roubini. 1998. "What Caused the Asian Currency and Financial Crisis, Part I and II." Working Paper Nos. 6833 and 6844. National Bureau of Economic Research, Cambridge, Mass.

Cothren, Richard D and Roger N. Waud. 1994. "On the Optimality of Reserve Requirements." Journal of Money, Credit, and Banking 26(4): 827-38.

Demsetz, Harold. 1974. "Two Systems of Belief About Monopoly." In Industrial Concentration: The New Learning, edited by Harvey S. Goldschmid, H. Michael Mann, and J. Fred Weston. Boston: Little, Brown.

Demsetz, Harold. 1973. "Industry Structure, Market Rivalry and Public Policy." Journal of Law and Economics 16(1): 1-9.

Dewatripont, Mathias and Jean Tirole. 1994. The Prudential Regulation of Banks. Cambridge, MA: MIT Press.

Djankov, Simeon, Rafael La Porta, Florencio Lopez-de-Silanes, and Andrei Shleifer. 2002. "The Regulation of Entry." Quarterly Journal of Economics 117: 1-37. 
Economides, Nicholas, R. Glenn Hubbard, and Darius Palia. 1996. "The Political Economy of Branching Restrictions and Deposit Insurance: A Model of Monopolistic Competition among Small and Large Banks." Journal of Law and Economics 39: 667-704.

Federal Deposit Insurance Corporation. 1960. Federal Deposit Insurance Corporation Data on Banks in the United States, 1920-1936. (computer file). Ann Arbor, Mich: Inter-university Consortium for Political and Social Research.

Folkerts-Landau, David and Carl-Johan Lindgren. 1998. Toward a Framework for Financial Stability. Washington, DC: International Monetary Fund.

Frankel, Allen B. 1998. "Issues in Financial Institution Capital in Emerging Market Economies." Federal Reserve Bank of New York Policy Review 4: 213-21.

Friedman, Milton and Anna J. Schwartz. 1963. A Monetary History of the United States, 18671960. Princeton: Princeton University Press.

Fry, Maxwell J. 1995. Money, Interest, and Banking in Economic Development. Baltimore, MD: Johns Hopkins University Press.

Gambs, Carl M. 1977. "Bank Failures: An Historical Perspective.” Monthly Review Federal Reserve Bank of Kansas City 62: 10-20.

Goldstein, Morris. 1996. The Case for an International Banking Standard. Washington, DC: Institute for International Economics.

Grossman, Richard S. 2001. "Double Liability and Bank Risk Taking." Journal of Money, Credit, and Banking 33(2): 143-59.

Grossman, Richard S. 1994. “The Shoe That Didn’t Drop: Explaining Banking Stability During the Great Depression." Journal of Economic History 54(3): 654-82.

Gruchy, Allan. 1937. Supervision and Control of Virginia State Banks. Charlottesville, VA: University of Virginia.

Herring, Richard and Robert C. Litan. 1995. Financial Regulation in the Global Economy. Washington, DC: Brookings Institution.

Hunter, William C., James A. Verbrugge, and David A. Whidbee. 1996. "Risk Taking and Failure in De Novo Savings and Loans in the 1980s." Journal of Financial Services Research 10: 235-71.

Jayaratne, Jith, and Philip E. Strahan. 1998. "Entry Restrictions, Industry Evolution, and Dynamic Efficiency: Evidence from Commercial Banking." Journal of Law and Economics 41: 239-73.

Jayaratne, Jith and Philip E. Strahan. 1997. "The Benefits of Branching Deregulation." Federal Reserve Bank of New York Policy Review 3: 13-29.

Kahane, Yehuda. 1977. “Capital Adequacy and the Regulation of Financial Intermediaries." Journal of Banking and Finance 1: 207-18. 
Kane, Edward. 1990. "Principal Agent Problems in the S\&L Salvage." Journal of Finance 45(3): 755-64.

Kim, D. and A. M. Santomero. 1988. "Regulation of Bank Capital and Portfolio Risk." Journal of Finance 35: 1219-33.

Kroszner, Randall S. and Phillip E. Strahan. 1999. "What Drives Deregulation? Economics and Politics of the Relaxation of Bank Branching Restrictions." Quarterly Journal of Economics 114(4): 1437-67.

Kroszner, Randall S. and Phillip E. Strahan. 2001. "Obstacles to Optimal Policy: The Interplay of Politics and Economics in Shaping Bank Supervision and Regulation of Reforms." In Prudential Supervision: What Works and What Doesn't, edited by Frederic S. Mishkin, pp.233-66. Chicago: University of Chicago Press.

Laderman, Elizabeth S., Ronald H. Schmidt, and Gary C. Zimmerman. 1991. "Location, Branching, and Bank Portfolio Diversification: The Case of Agricultural Lending." Federal Reserve Bank of San Francisco Economic Review, 24-38.

Laffont, Jean Jaques and Tirole, Jean. 1991. "The Politics of Government Decision-Making: A Theory of Regulatory Capture.” Quarterly Journal of Economics 106(4): 1089-127.

Mason, Joseph, Ali Anari, and James Kolari. 2000. "The Speed of Bank Liquidation and the Propagation of the U.S. Great Depression." In Bank Structure and Competition Conference Proceedings, pp.320-45. Chicago: Federal Reserve Bank of Chicago.

Mishkin, Frederic S. 2001. "Prudential Supervision: Why Is it Important and What Are the Issues?" In Prudential Supervision: What Works and What Doesn't, edited by Frederic S. Mishkin, pp.1-29. Chicago: University of Chicago Press.

Mishkin, Frederic S. 1999. "Lessons from the Asian Crisis." Journal of International Money and Finance, 18: 709-23.

Mitchener, Kris James. 2001. "Regulatory Chaos and the Great Depression: The Evolution of State Bank Regulation.” Unpublished Manuscript, University of California, Berkeley.

Martimont, David. 1999. "The Life Cycle of Regulatory Agencies: Dynamic Capture and Transaction Costs." Review of Economic Studies 66: 929-47.

Neal, Linwood O. 1942. The History and Development of State Bank Supervision in Oklahoma. New Brunswick, NJ: Rutgers University.

Neyapti, Bilin and Nergiz Dincer. 2000. "Measuring the Quality of Bank Regulation and Supervision and Its Macroeconomic Effects: An Application to Transition Economies." Working Paper, Bilkent University.

Polk's Bankers Encyclopedia Co. 1929. Polk’s Bankers Encyclopedia, March 1929. Detroit, MI: Polk’s Bankers Encyclopedia Co.

Robertson, Ross. 1968. The Comptroller and Bank Supervision. Washington, D.C.: Office of the Comptroller of the Currency. 
Rose, Peter S. and William L. Scott. 1978. "Risk in Commercial Banking: Evidence from Postwar Failures.” Southern Economic Journal (July): 90-106.

Rossi, Marco. 1999. "Financial Fragility and Economic Performance in Developing Economies: Do Capital Controls, Prudential Regulation, and Supervision Matter?" Working Paper. International Monetary Fund, Washington, DC.

Sprague, Oliver M.W. 1903. "Branch Banking in the United States." Quarterly Journal of Economics 27: 242-60.

Stauffer, Robert F. 1981. “The Bank Failures of 1930-1931.” Journal of Money, Credit, and Banking 13(1): 109-13

Stiroh, Kevin J.and Philip E. Strahan. 2003. "Competitive Dynamics of Deregulation: Evidence from U.S. Banking." Journal of Money, Credit, and Banking 35: 801-28.

Study Commission for Indiana Financial Institutions. 1932. Report. Indianapolis, IN.: SeventySeventh General Assembly.

Temin, Peter. 1976. Did Monetary Forces Cause the Great Depression? New York: W.W. Norton.

Tippetts, Charles S. 1929. State Banks and the Federal Reserve System. New York: D. Van Nostrand Company.

Wacht, Richard F. 1968. "Branch Banking and Risk." Journal of Financial and Quantitative Anaylsis 3 (March): 97-107.

Wheelock, David C. 1995. "Regulation, Market Structure, and the Bank Failures of the Great Depression.” Federal Reserve Bank of St. Louis Review 77(2): 27-38.

Wheelock, David C. 1992. "Regulation and Bank Failures: New Evidence from the Agricultural Collapse of the 1920s." Journal of Economic History 52(4): 806-25.

White, Eugene N. 1984. "A Reinterpretation of the Banking Crisis of 1930." Journal of Economic History 44(1): 119-38.

White, Eugene N. 1983. The Regulation and Reform of the American Banking System, 19001929. Princeton, NJ: Princeton University Press.

Wicker, Elmus. 1996. The Banking Panics of the Great Depression. Cambridge: Cambridge University Press.

Wicker, Elmus. 1980. "A Reconsideration of the Causes of the Banking Panic of 1930." Journal of Economic History 40(3): 571-83. 
Table 1. Banks by Charter Status

All Commercial

Banks

$\underline{\text { State Banks }}$ National Banks

Total Failures, 1929-33

$$
9,440
$$

7,429

2,011

Share of All Bank Failures (\%)

$79 \%$

$21 \%$

Average Failure Rate (1929-33)

$9.2 \%$

$10.2 \%$

$6.8 \%$

Standard Deviation of Failure Rate

10.1

11.2

8.9

$\%$ of Deposits in Failed Banks

(Average 1929-33)

$5.6 \%$

$8.0 \%$

$4.1 \%$

Standard Deviation of \% of Deposits

In Failed Banks

10.3

14.6

12.8

Total Deposits (\$billions), 1929

49.4

27.8

21.6

Share of Total Deposits

$56.3 \%$

$43.7 \%$

Total Banks in 1929

24,970

17,440

7,530

Share of Total Banks

$69.8 \%$

$30.2 \%$

Deposits per Bank (\$millions), 1929

1.98

1.59

2.87

Sources: Calculations use bank suspension data from Federal Reserve Bulletin, September 1937; number of banks by charter status and deposit data are from Board of Governors, Federal Reserve System (1959). 
Table 2. Summary Statistics on Bank Regulation and Financial Supervision

$\underline{\text { Variable }}$

Capital Requirement in 1929 (\$1000)

(Minimum Charter Capital Required)

Reserve Requirement, 1929

Branching Banks as a Percent of All

Banks, 1929

Number of States with Statewide

Branching, 1929

Number of States Explicitly Prohibiting

Branching, 1929

Length of State Bank Supervisor's Term (years)

Banks per Examiner, June 1929

Supervisors' Salary (\$), 1929

Examiners' Salary (\$), 1929

Assets per Examiner, 1929

Percent of States Whose Supervisors

Have Sole Power to Charter Banks

Percent of States Whose Supervisors

Have Sole Power to Liquidate Banks

Four-firm concentration ratio (\%),

All Banks, 1929

Share of Small Banks Located in State, 1929
Standard

Mean Deviation Minimum Maximum

$\begin{array}{rrrr}25 & 16.3 & 0 & 100 \\ 15 \% & 3.2 \% & 7 \% & 20 \% \\ 5 \% & 9 \% & 0 \% & 46 \%\end{array}$

8

23

$\begin{array}{rrrr}3.8 & 1.0 & 2 & 6 \\ 29.4 & 19.0 & 1.5 & 75.7 \\ 5,957 & 2,113 & 3,600 & 12,000 \\ 3,034 & 625 & 2,000 & 5,100 \\ 27,103 & 22,343 & 1,510 & 140,842\end{array}$

$41.7 \%$

$60.4 \%$

$28.4 \% \quad 15.5 \% \quad 7.3 \% \quad 82.5 \%$

$21 \% \quad 22 \% \quad 0 \% \quad 87 \%$

Notes: Medians rather than means are given for minimum charter capital and reserve requirements. Capital requirements are those that applied to the smallest municipality in the state. Reserve requirements are for the demand deposits of country banks. The small banks measure is defined as the percentage of state-chartered banks in a state that are located in counties where the average deposits per bank are in the lowest third of all U.S. counties.

Sources: Bank failure data are from Federal Reserve Bulletin (September 1937). Data on branching laws and reserve requirements are from Federal Reserve Bulletin (November 1928, February and December 1929, and September 1930). Capital requirements and data for constructing the four-firm concentration ratio are from Polk's Bankers Encyclopedia Co. (1929). Data on length of supervisor's term, banks and assets per examiner, salaries of supervisory staff, and charter and liquidation authority are from American Bankers Association (1929). The share of small banks located in a state is calculated using data from FDIC (1960). Data on finance industry salaries are from U.S. Census of Business (1936). 
Table 3. Explaining the Variation in State Bank Suspension Rates, 1929-1933

(Dependent Variable: Annual Average Suspension Rate for state-chartered, non-member banks)

Independent Variable

Failure rate for national banks

(standard error)

[p value]

Sole authority to charter banks

Sole authority to liquidate banks

Supervisors' Term

Banks per Examiner

Capital Requirement

(\$1000s)

Reserve Requirement

State banks with branches (\%)

Bank Industry Structure Controls

Year Dummies

Adjusted R-Squared

Number of Observations

\section{Column 1}

3.502 **

1.722

0.043

-5.363 **

2.191

0.015

1.873 *

1.048

0.075

$-0.059$

0.060

0.322

$-0.057$

0.057

0.323

0.087

0.357

0.808

\begin{abstract}
-0.186 *
0.102

0.070
\end{abstract}

NO
NO
0.07
240

\section{Column 2}

1.089 ***

0.093

0.000

1.087

1.045

0.299

-3.414 ***

1.038

0.001

1.592 ***

0.492

0.001

$-0.019$

0.027

0.487

$-0.013$

0.030

0.655

0.336 ***

0.129

0.010

-0.128 ***

0.044

0.004

NO

NO

0.75

240 $\underline{\text { Column } 3}$

1.013 ***

0.128

0.000

1.481

1.151

0.200

1.513

1.038

0.146

-3.639 ***

1.059

0.001

$-3.659 * \star \star$

1.033

0.000

$\begin{array}{ll}1.612 \text { *** } & 1.611 \text { *** } \\ 0.524 & 0.517 \\ 0.002 & 0.002\end{array}$

$-0.018$

$-0.018$

0.029

0.527

0.527

$-0.031$

0.028

0.267

0.279

0.403 ***

0.152

0.009

$\begin{array}{ll}0.153 & 0.009\end{array}$

-0.129 **

$-0.129 * \star \star$

0.060

0.031

0.032

YES

YES

0.19

240

Notes: Industry structure controls are a four-bank concentration ratio for state banks, the average deposits for state banks, the (average) percentage of state bank assets that were cash or government bonds (risky assets), and the average capital-asset ratio for state banks. Regressions also include a constant term and state characteristics described in the text (not reported). Weighted least squares regressions use total banks in each state as weights. Standard errors are Eicker-White heteroskedasticity consistent. Stars indicate significance at $1\left(^{\star \star *}\right), 5\left(^{\star *}\right)$, and $\left.10^{\star}\right)$ percent levels, respectively. The sample period is 1929-33. The dependent variable in column 4 is the difference between the state and national failure rates.

Sources: See Tables 1 and 2. 
Table 4. Panel A: Correlation Matrix for Regulatory and Supervisory Variables

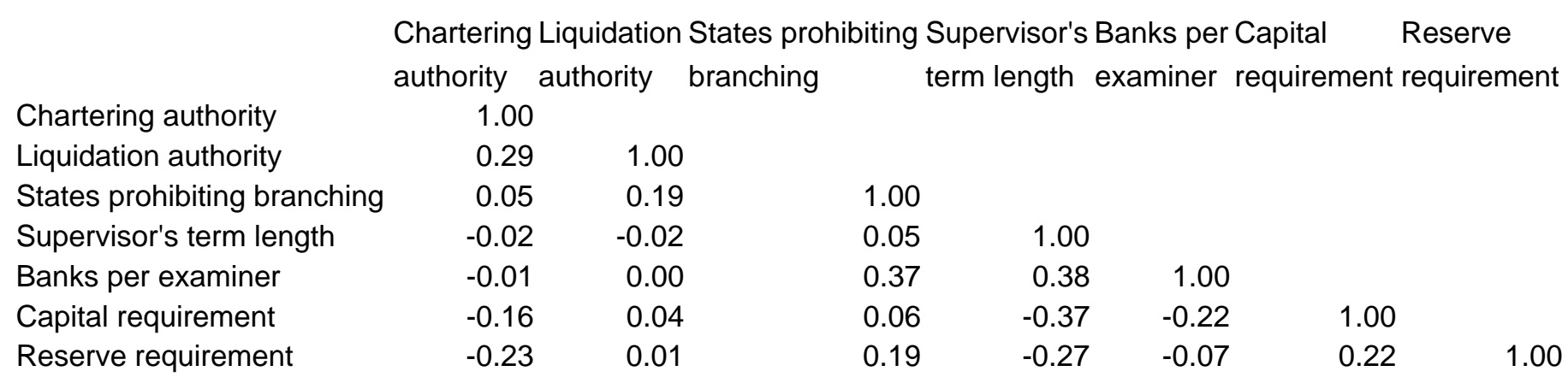


Table 5. Alternative Measures of Banking Distress \& Sensitivity Tests

\begin{tabular}{|c|c|c|c|c|}
\hline \multirow{2}{*}{ Independent Variable } & \multicolumn{3}{|c|}{ Dependent Variable } & \multirow[b]{2}{*}{$\begin{array}{c}\text { Suspended } \\
\text { Assets }\end{array}$} \\
\hline & $\begin{array}{l}\text { Suspended } \\
\text { Deposits }\end{array}$ & $\begin{array}{c}\text { Suspended } \\
\text { Assets }\end{array}$ & $\begin{array}{l}\text { Suspended } \\
\text { Deposits }\end{array}$ & \\
\hline \multirow{3}{*}{$\begin{array}{l}\text { National bank distress } \\
\text { (standard error) } \\
\text { [p value] }\end{array}$} & $0.208 * * *$ & $0.225 * \star \star$ & $0.211 * \star \star$ & $0.225 * * *$ \\
\hline & 0.060 & 0.061 & 0.064 & 0.064 \\
\hline & 0.001 & 0.000 & 0.001 & 0.001 \\
\hline \multirow[t]{3}{*}{ Sole authority to charter banks } & 0.258 & 0.228 & 0.323 & 0.341 \\
\hline & 0.232 & 0.240 & 0.224 & 0.228 \\
\hline & 0.269 & 0.343 & 0.151 & 0.136 \\
\hline \multirow[t]{3}{*}{ Sole authority to liquidate banks } & -0.304 & -0.289 & -0.361 & -0.406 \\
\hline & 0.251 & 0.261 & 0.259 & 0.259 \\
\hline & 0.227 & 0.270 & 0.164 & 0.119 \\
\hline \multirow[t]{3}{*}{ Supervisor's Term (years) } & $0.421 * * *$ & $0.386 * \star \star$ & $0.483 * \star *$ & $0.472 * * *$ \\
\hline & 0.119 & 0.121 & 0.119 & 0.119 \\
\hline & 0.000 & 0.002 & 0.000 & 0.000 \\
\hline \multirow[t]{3}{*}{ Banks per Examiner (1928) } & 0.009 & 0.008 & 0.010 * & 0.009 \\
\hline & 0.006 & 0.006 & 0.006 & 0.006 \\
\hline & 0.128 & 0.166 & 0.066 & 0.108 \\
\hline \multirow{3}{*}{$\begin{array}{l}\text { Capital Requirement } \\
(\$ 1000 \text { s) }\end{array}$} & 0.007 & 0.006 & 0.007 & 0.006 \\
\hline & 0.006 & 0.007 & 0.006 & 0.007 \\
\hline & 0.302 & 0.382 & 0.304 & 0.391 \\
\hline \multirow[t]{3}{*}{ Reserve Requirement } & 0.089 ** & 0.082 ** & $0.117 * \star \star$ & 0.112 *** \\
\hline & 0.042 & 0.043 & 0.041 & 0.041 \\
\hline & 0.037 & 0.056 & 0.005 & 0.007 \\
\hline \multirow[t]{3}{*}{ State banks with branches (\%) } & $-0.047 * * *$ & $-0.044 * * *$ & $-0.038 * *$ & -0.036 ** \\
\hline & 0.015 & 0.015 & 0.017 & 0.017 \\
\hline & 0.002 & 0.004 & 0.029 & 0.038 \\
\hline \multirow{3}{*}{$\begin{array}{l}\text { Assets per bank examiner } \\
\quad(\$ 1000 \text { s })\end{array}$} & & & 0.009 & $0.009 *$ \\
\hline & & & 0.005 & 0.006 \\
\hline & & & 0.103 & 0.087 \\
\hline \multirow{3}{*}{$\begin{array}{l}\text { Wage Differential: Examiners - } \\
\text { Finance Industry Executives } \\
\quad(\$ 1000 \text { s) }\end{array}$} & & & -0.197 & -0.216 \\
\hline & & & 0.147 & 0.145 \\
\hline & & & 0.181 & 0.139 \\
\hline Adjusted R-Squared & 0.76 & 0.76 & 0.77 & 0.77 \\
\hline Number of Observations & 240 & 240 & 240 & 240 \\
\hline
\end{tabular}

Notes: WLS Estimation (with a constant term) and Eicker-White correction for standard errors. Bank industry structure control variables and year dummies were included in all the regressions shown in the table. See Table 3 for industry controls and weights, and Tables 1 and 2 for sources. The sample period is 1929-33. Columns $1 \& 3$ use the $(\log )$ share of deposits of state-chartered, non-member banks that are suspended as the dependent variable. Columns $2 \& 4$ uses the $(\mathrm{log})$ share of loans and investments that are suspended in state-chartered, non-member banks as the dependent variable. National bank distress corresponds to the (log) share of suspended deposits in national banks (columns 1\&3) and the (log) share of suspended assets in national banks (columns $2 \& 4$ ). 
Table 6. Endogeneity \& Instrumental Variables Estimation of Suspension Rates, 1929-1933

(Dependent Variable: Annual Average Suspension Rate for state-chartered, non-member banks)

\section{Independent Variable}

Failure rate for national banks

(standard error)

[p value]

Sole authority to charter banks

Supervisor's Term (years)

Banks per Examiner

Capital Requirement

(in \$1000s)

Reserve Requirement

Statewide Branching Permitted

State Bank Suspension Rate, 1921-28

\section{Estimation (1)}

1.079 ***
0.149
0.000

0.209

1.574

0.895

$-3.282 * \star \star$

1.123

0.004

$1.672 * * *$

0.630

0.009

$-0.026$

0.034

0.437

0.069

0.138

0.617

$-0.208$

0.381

0.586

$-5.022$

3.206

0.119

\section{Estimation (2)}

1.077 ***

0.149

0.000

0.025

1.552

0.987

-3.222 ***

1.140

0.005

1.604 **

0.661

0.016

$-0.025$

0.035

0.470

0.071

0.137

0.607

$-0.217$

0.381

0.569

-5.183 *

3.110

0.097
Lagged

Regulation

$1.002 * * *$

0.128

0.000

0.582

1.060

0.584

-3.659 ***

1.046

0.001

1.783 ***

0.539

0.001

$-0.028$

0.029

0.327

$-0.049$

0.031

0.120

0.313 **

0.130

0.017

-4.387 ***

1.355

0.001
0.157

0.291

0.589

YES

YES

0.74

235
YES

YES

0.74

235
YES

YES

0.77

240

Notes: A constant term was also included. Instruments were constructed for bank regulation (branching laws, reserve requirements, and capital requirements) variables. Wyoming is excluded due to missing values for some of the instrumental variables. Column 3 is weighted least squares with robust standard errors, where the regulatory variables are fixed at their 1924 values.

The legal status of statewide branching is substituted for state banks with branches.

Sources: See Tables 1 and 2, and Appendix 1 for details on instrumental variables. 


\section{Figure 1. Bank Failure Rates during the Great Depression}
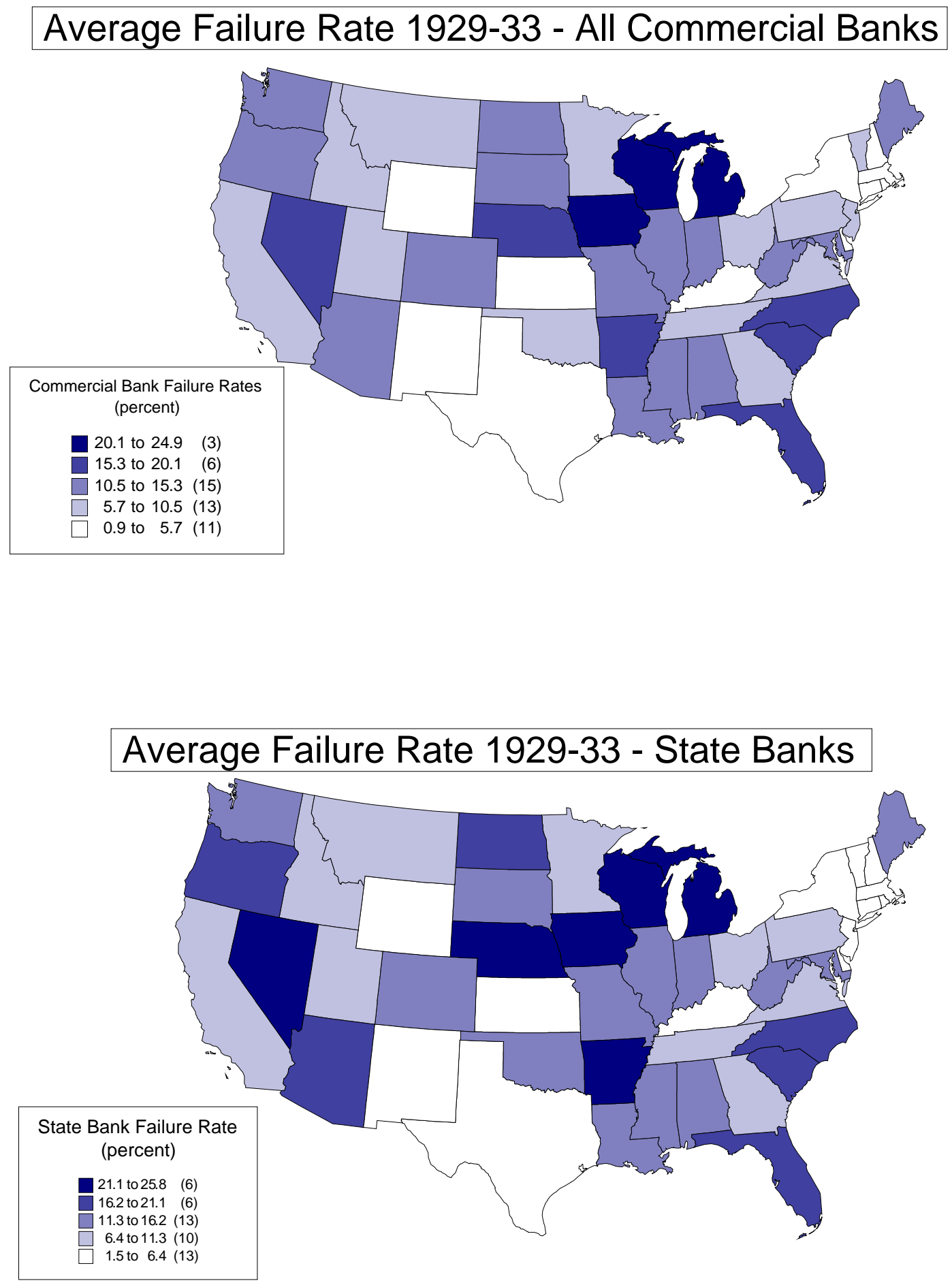

Source: Calculations based on Federal Reserve Bulletin, September 1937 and Board of Governors, Federal Reserve System (1959). 